\title{
New data on the stratigraphy of the Paleogene in Solnik area, Eastern Bulgaria
}

\section{Нови данни за стратиграфията на Палеогена в Солнишката площ, Източна България}

\author{
Boris Valchev, Hristo Dimitrov \\ Борис Вълчев, Христо Димитров
}

\begin{abstract}
University of Mining and Geology "St Ivan Rilski”, 1, Prof. Boyan Kamenov str., 1700 Sofia, Bulgaria; E-mails: b_valchev@mgu.bg; hristo_dimitrov@mgu.bg
\end{abstract}

\begin{abstract}
Based on lithostratigraphic reinterpretation of five borehole sections and lithostratigraphic interpretation of two seismic profiles, new data on the Dvoynitsa Formation's lithology, subdivision and spatial distribution were obtained. The Armera and Gebesh Members were recognized in the area of the villages of Solnik and Bardarevo, as their spatial relationships and distribution are visualized by drawing up of four geological cross-sections.
\end{abstract}

Keywords: Paleogene, Dvoynitsa Fm., borehole logs, seismic profiles, Solnik area.

\section{Introduction}

The Paleogene sediments crop out broadly in the tectonically complicated area of the villages of Solnik and Bardarevo and their surroundings (known as Solnik area) which is located along the border between the Eastern Fore-Balkan and Eastern Balkan (Luda Kamchia) zones (Fig. $1 a, h)$. Previously, they have been referred to different lithostratigraphic units. Pollak (1933) described "exotisches Konglomerat", "Basalkonglomerat", "Molasseflysch", "südliche (Čifte Dere) Fazies", and "Gebešfazies". Kânčev (1995) described these rocks as "conglomerate formation" of middle-late Eocene age (cropping out in the Eastern Fore-Balkan), "breccia formation" of Paleocene age, "thick-bedded flysch formation" of late Paleocene-middle Eocene age, and "Gebesh flysch Formation" of early Eocene age (including the last two units of Pollak, 1933), respectively. Juranov and Pimpirev (1989) united the similar rocks, cropping out in coastal region of the Eastern Balkanides between the towns of Byala and Obzor into the Dvoynitsa Formation. Juranov et al. $\left(1996 \mathrm{f}^{1}\right)$ referred the Paleogene sedimentary rocks in Solnik area to "breccia-conglomerate formation" (corresponding to the "Basalkonglomerat" of Pollak, 1933, and the "breccia formation" of Kânčev, 1995) of latest Paleocene-earliest Eocene age and the Dvoynitsa Formation (early-middle Eocene age). Later on, Vangelov and Sinnyovsky (2011) summarised all available data on the lithology, distribution and chronostrtatigraphic range of the formation and proved that it is largely distributed in the Eastern Balkanides. These authors motivated defining of three members of the Dvoynitsa Formation (the Armera, Gebesh, and Goritsa Members), noting that there is no section containing the entire formation's lithological types.

The present short communication represents new data on the Dvoynitsa Formation's lithology, subdi-

\footnotetext{
${ }^{1}$ Juranov, S., M. Antonov, G. Baltakov, D. Vangelov, V. Jelev, D. Sinnyovsky, I. Choleev. 1996f. Report on the Geological Mapping at a Scale 1:25 000 and Geomorphologic Mapping at a Scale 1:50 000 of Parts of Kamchia Mountain and Northern Slope of Emine Mountain. Sofia, Ministry of Energy, National Geological Fund, report IV-439, 248 p. (in Bulgarian, unpublished).
} 
vision and spatial distribution based on lithostratigraphic reinterpretation of five borehole $\operatorname{logs}$ and lithostratigraphic interpretation of two seismic profiles. Four geological cross sections visualize the deep geological structure of the area between the villages of Bardarevo and Sonlik (Fig. 1a).

\section{Results}

On the basis of primary lithological data derived from the fife borehole sections we referred the Paleogene rocks into two formal lithostratigraphic units: the Gebesh and Armera Members of the Dvoynitsa Formation.

The Gebesh Member is composed of packages of gray middle- to coarse-grained thick- to middle- bedded sandstones (the "thick-bedded flysch formation" of Kânčev, 1995), and thin- to middle-bedded alternation of sandstones, siltstones, shales, and marls (the "Gebesh flysch Formation" of Kânčev, 1995). The first lithological type was recorded in three borehole sections near the village of Solnik (C-32, C-33, and C-34 - Fig. 1b-e, g), as it occupies different levels in the sections. Rare thin interbeds of grey-greenish to red clays were recorded predominantly in the lower parts of these packages. The second lithological type was established at the same borehole sections. It represents a thin-rhythmic flysch as the rhythm's thickness varies from 5 to $40 \mathrm{~cm}$. The sandstones are gray to yellowish, fine-grained, while the siltstones, shales and marlstones are gray. The alternation usually interbeds
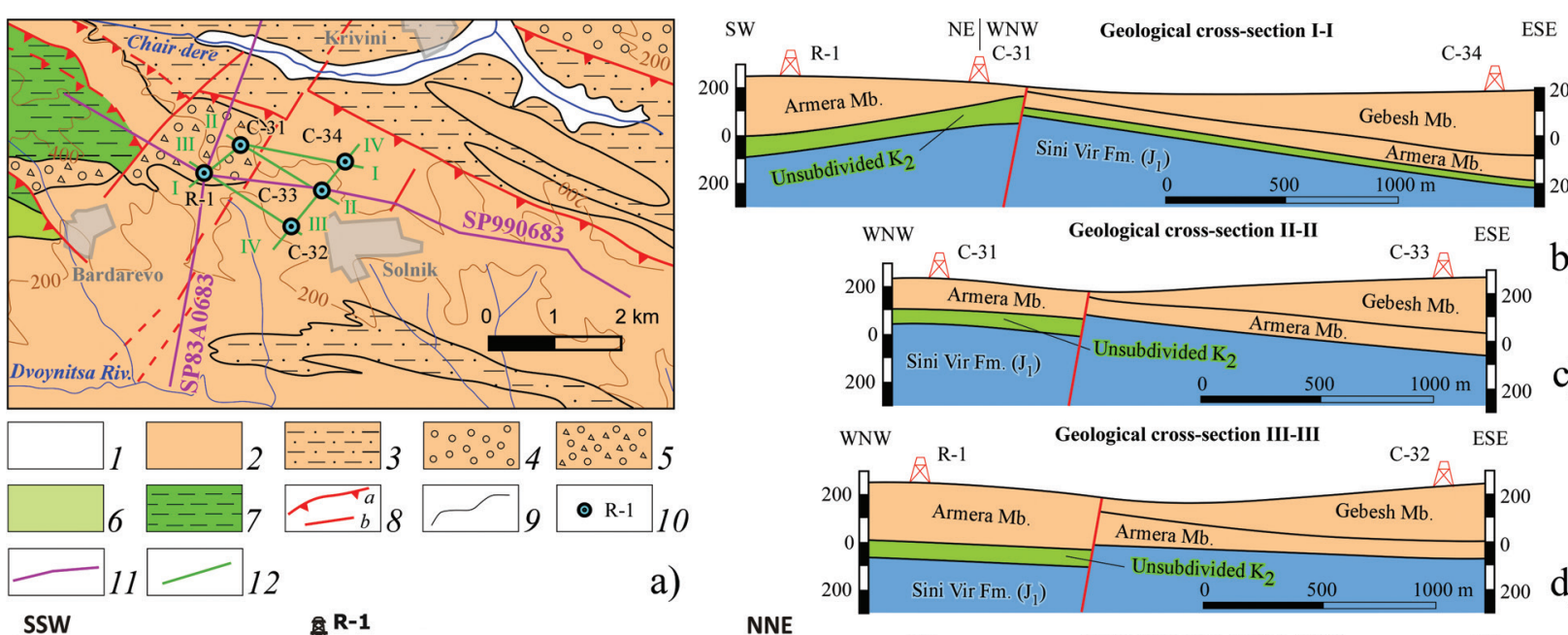

ESE
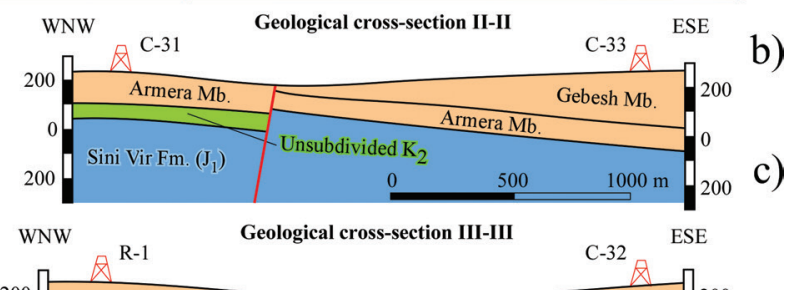

\section{)}
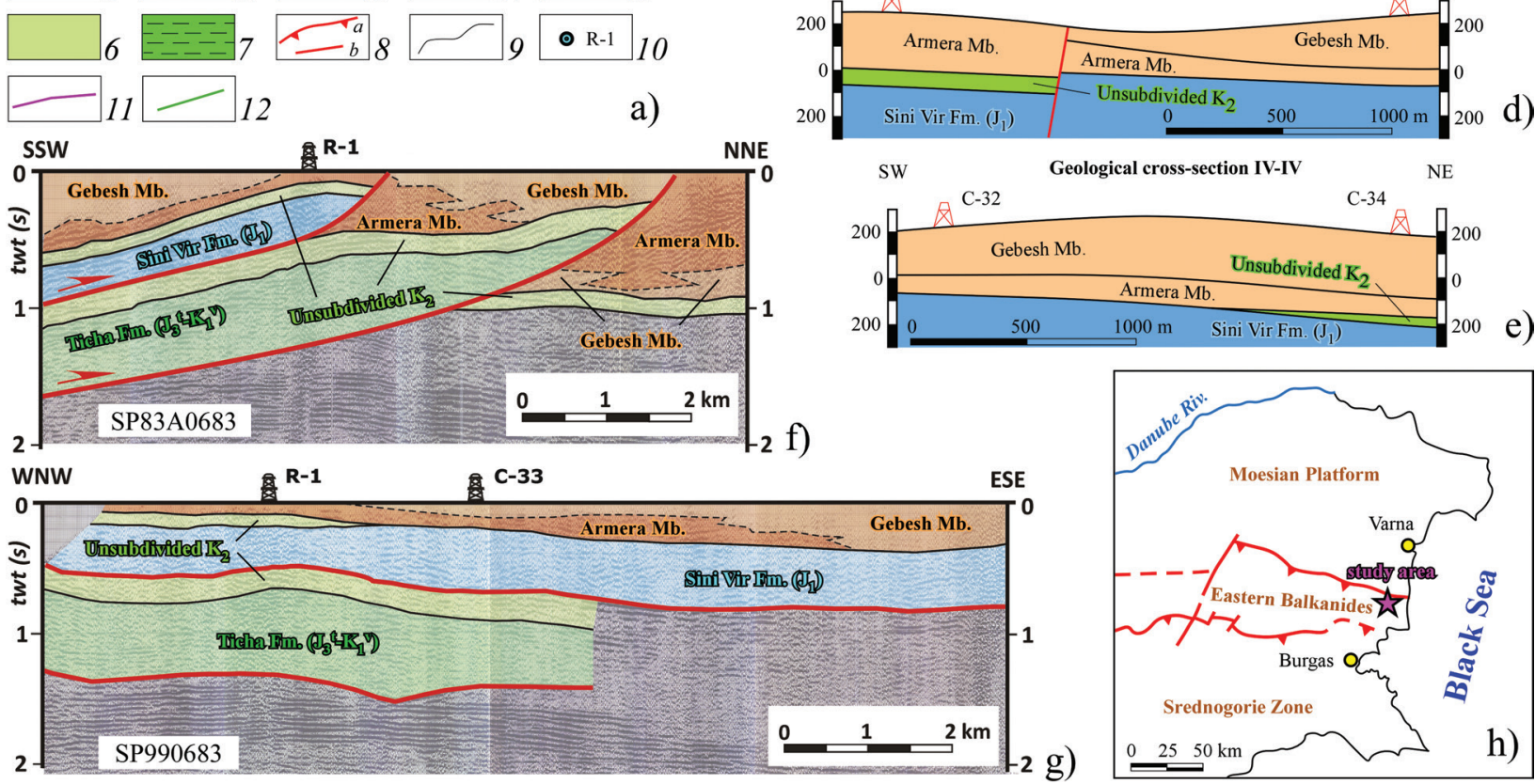

Fig. 1. $a$, geologic map of the Solnik area (after Kânčev, Gerčeva, 1992; Juranov et al., 1996f, modified) with the location of the studied borehole sections, seismic profiles, and the lines of the geological cross-sections: 1, Quaternary, 2-5, Dvoynitsa Fm. (Gebesh Mb.: 2, sandstones, 3, thin-bedded sandstones, siltstones, marlstones, Armera Mb.: 4, conglomerates, 5, breccia-conglomerates), 6, Vetrila and Byala Fms (limestones with chert nodules, alternation of limestones and marlstones; Campanian-Maastrichtian), 7, flysch fm. (rhythmic alternation of sandstones, limestones and marlstones; Cenomanian-Campanian), 8 , faults ( $a$, reverse fault, $b$, normal fault), 9 , lithostratigraphic boundary, 10 , borehole, 11 , seismic profile, 12 , geological cross-section; $b-e$, geological cross-sections ( $b$, I-I, $c$, II-II, $d$, III-III, $e$, IV-IV); f, g) seismic profiles ( $f$, SP83A0683, $g$, SP990683); $h$, tectonic subdivision of Eastern Bulgaria (after Dabovski, Zagorchev, 2009) with location of the studied area 
the packages of thick- to middle-bedded sandstones. The thickness of the Gebesh Member varies from $177 \mathrm{~m}$ (C-33 borehole) to $294 \mathrm{~m}$ (C-34 borehole).

The Armera Member comprises breccias and breccia-conglomerates (the "conglomerate formation" of Kânčev, 1995, or the "breccia-conglomerate formation" of Juranov et al., 1996f). They are poorly-sorted, polygenic, including pebbles to boulders of Triassic dolostones, Jurassic quartzites, shales and siderite nodules, Cenomanian sandstones, and other Cretaceous rocks (limestones, marlstones, volcanics, quartz grains). The matrix is grey to black, sandy to silty. The member was recorded in all studied borehole sections (Fig. 1b-e), as its thickness varies from $64 \mathrm{~m}$ (C-32 borehole) to $240 \mathrm{~m}$ (R-1 borehole).

The western borehole sections (R-1 and C-31 boreholes) reveal that the Dvoynitsa Formation is represented only by the Armera Member. Here it covers unsubdivided Upper Cretaceous sedimentary rocks (gray, thin- to coarse-grained thin-bedded limy sandstones), as the boundary is an unconformity. In the eastern borehole sections (C-32, C-33, and C-34 boreholes) the Dvoynitsa Formation includes both the Gebesh and Armera Members. In all three sections the first one covers with sharp lithological contact the second one. Here the lower boundary of the formation is an unconformity with the unsubdivided Upper Cretaceous or the Sini Vir Formation (Lower Jurassic). The total thickness of the Dvoynitsa Formation varies from 122 m (C-31 borehole) to $376 \mathrm{~m}$ (C-34 borehole).

The lithostratigraphic interpretation of the seismic profiles (Fig. $1 f, g$ ) confirmed the presence of the Gebesh and Armera Members and visualised their contacts and spatial relationships and distribution. It also reveals the allochthonous position of the almost entire Solnik area in the border area between the Eastern Fore-Balkan and Eastern Balkan.

\section{Conclusions}

This study confirmed the various lithology of the Dvoynitsa Formation - three lithological types were recorded. Their complex spatial relationships, established in other parts of Eastern Balkanides (Vangelov, Sinnyovsky, 2011) and the Dolna Kamchia Basin (Valchev et al., 2018; Valchev, Dimitrov, 2019) were observed in the Solnik area, as well. The presence of two members (the Gebesh and Armera) was proved. The collected new data are a contribution to the Paleogene stratigraphy of Eastern Balkanides and they are a reliable base for further paleogeographic reconstructions.

\section{References}

Dabovski, H., I. Zagorchev. 2009. Alpine tectonic subdivision of Bulgaria. - In: Zagorchev, I., H. Dabovski, T. Nikolov (Eds.). Geology of Bulgaria. Vol. II, Mesozoic Geology. Sofia, "Prof. Marin Drinov" Publishing House, 30-37 (in Bulgarian with English abstract).

Juranov, S., H. Pimpirev. 1989. Lithostratigraphy of the Upper Cretaceous and Paleogene in the coastal part of East Stara Planina. - Rev. Bulg. Geol. Soc., 50, 2, 1-18 (in Bulgarian with English abstract).

Kânčev, I. 1995. Explanatory Note to the Geological Map of Bulgaria on Scale 1:100 000. Dolni Čflik Map Sheet. Sofia, Committee of Geology and Mineral Resourses, Geology \& Geophysics Corp., Avers, 113 p. (in Bulgarian with English abstract).

Kânčev, I., Y. Gerčeva. 1992. Geological Map of Bulgaria on Scale 1:100 000. Dolni Ciflik Map Sheet. Sofia, Committee of Geology and Mineral Resources, Geology \& Geophysics Corp.

Pollak, A. 1933. Geologische Untersuchungen über das Endstück Ostbalkans. - Abh. Math.-Phys. Kl. der Säch. Akad. Wiss., 41, 7, 1-60.

Valchev, B., H. Dimitrov, D. Sachkov, S. Juranov. 2018. New data on the Dvoynitsa Formation distribution in the onshore part of the Dolna Kamchiya basin based on 3D lithological modeling. - C. R. Acad. Bulg. Sci., 71, 12, 1652-1656; https://doi.org/10.7546/CRABS.2018.12.09.

Valchev, B., H. Dimitrov. 2019. A new view to the spatial distribution of the Paleogene lithostratigraphic units in the offshore part of the Dolna Kamchiya basin based on seismic profile's interpretation. - Rev. Bulg. Geol. Soc., 80, 2, 61-69.

Vangelov, D., D. Sinnyovsky. 2011. New data about the Dvoynitsa Formation distribution, lithology and chronostratigraphic range, East Bulgaria. - Ann. Univ. de Sofia, Fac. géol. et géogr., 49, 1-géol., 43-70 (in Bulgarian with English abstract). 